\title{
Heavy Metals Levels in Plastics Housing of Televisions: Is there a changing trend across three decades (1980-2000)?
}

\section{Chioma Grace Okenwa-Ani $(D)$, Nnamdi Lawrence Obasi $(D)$ Alfred Ezinna Ochonogor $(D)$ Janefrances Ngozi Ihedioha*it}

Department of Pure and Industrial Chemistry, University of Nigeria Nsukka, Enugu State, Nigeria.

\begin{tabular}{ll}
\hline Article Info & A B S T R A C T \\
\hline Article Type: & Background: \\
Original Research & This study investigated the concentration of some heavy metals in plastic \\
\hline Article History: & housing of televisions produced over three decade $(1980-2000)$ with the \\
Received: 22.04 .2019 & aim of providing information and comparing the trend in the concentration \\
Accepted:01.06.2019 & of these metals.
\end{tabular}

\section{Methods:}

\section{* Corresponding Author:}

Janefrances Ngozi Ihedioha

Department of Pure and Industrial Chemistry, University of Nigeria Nsukka, Enugu State, Nigeria. E-mail:

janefrances.ihedioha@unn.edu.ng
The heavy metal concentrations were determined by atomic absorption spectroscopy after acid digestion using a 1:1 mixture of sulphuric and nitric acid.

\section{Results:}

The mean concentration of the heavy metals $(\mathrm{mg} / \mathrm{kg})$ in the television sets for 1980s, 1990s and 2000s, respectively, were as follows: 12.75 (Nd); 1.32 $(\mathrm{Pb}) ; 1.84,1.47 \& 2.79(\mathrm{Ni}) ; 1.53,16.19 \& 40.42(\mathrm{Ag}) ; 82.24,159.69 \&$ 113.29 (Zn); 7.12, 4.23 \& $5.26(\mathrm{Cr}) ; 3.26,2.76 \& 2.39(\mathrm{Cu}) ; 4.84,24.05 \&$ 26.67 (V); 9.30, $8.40 \& 12.63$ (Co); 2.59, $4.05 \& 4.28$ (Cd).

\section{Conclusion:}

Although the mean concentrations for $\mathrm{Zn}, \mathrm{Cu}$ and $\mathrm{Ag}$ in the television samples were relatively high, compared to the total threshold limit concentration (TTLC), they were below the threshold limit. These results suggest that there may not be any immediate environmental hazard posed from the TV plastic housings. The correlations analysis showed that most of the metals declined in TV housings over the subsequent decades.

Keywords:

Environmental Hazards, Heavy Metals, Plastics, Television, 1980's to 2000's Decades.

How to cite this paper

Okenwa-Ani CG, Obasi NL, Ochonogor AE, Ihedioha JN. Heavy Metals Levels in Plastics Housing of Televisions: Is there a changing trend across three decades (1980-2000)? Iran J Toxicol.2019;13 (3):27-32

\section{INTRODUCTION}

Electrical and electronic products, such as computers, mobile phones, television, digital recorders and many other household items continue to revolutionize social communication, entertainment, transportation, education and healthcare worldwide ( $\underline{1})$. There is no indication that this revolution will abate soon. Technical innovation will continue to be a cornerstone of social progress and advanced electronics are leading the way (2). Plastics have unique physical and electrical insulating properties, such as strength, resistance, flexibility, lack of electrical conduction. These properties are important for electronic devices, both for internal and external uses, especially in televisions and other household electronic devices.

Plastics have been the second largest components in Waste Electrical and Electronic Equipment (WEEE) and approximately $30 \%$ of the mass electronic scrap consists of plastics $(\underline{3,4})$. In Western Europe, plastic consumption by the industry was 2.78 million tons in 2002 and the quantity increased to 3.91 million tons, which is a rise of approximately 1.13 million tons for 2005 (므). Elements such as lead, cadmium, chromium, mercury, bromine, tin and antimony currently are or have been added to polymers as pigments, fillers, UV stabilizers and flame retardants. Typically, these materials do not chemically bind to plastic molecules but rather they create a suspension in the solid plastic polymer (므). Therefore, they may potentially dislodge from the plastic matrix over time. A visible symptom of such process is hazing on the surface of plastics caused by migration of bromine from the bulk of the material to the surface. This can create serious health problems and environmental hazards, as most of these elements are known to be toxic to humans.

Heavy metals are defined as elements with relatively high density compared to water molecule (ㄱ). Assuming that heavy molecular weight is associated with toxicity, heavy metals, including metalloids, (such as arsenic) are able to induce toxicity in humans even at trace amounts of exposure (ㅁ) . Any metal (or metalloid) species may be considered a contaminant if it is unwanted or occurs in a form or concentration that 
is detrimental to humans or environment ( $\underline{9})$. Metals/metalloids include lead $(\mathrm{Pb})$, cadmium (Cd), mercury (Hg), arsenic (As), chromium (Cr), copper $(\mathrm{Cu})$, vanadium $(\mathrm{V})$, selenium $(\mathrm{Se})$, nickel $(\mathrm{Ni})$, silver $(\mathrm{Ag})$, and zinc $(\mathrm{Zn})$. Other less common metallic contaminants include aluminum (Al), cesium (Cs), cobalt (Co), manganese (Mn), molybdenum (Mo), strontium (Sr), and uranium (U). These metals are significant environmental pollutants and their toxicity is a problem of increasing concern for ecological, nutritional, environmental and evolutionary reasons. Some of them; however, are essential for the body metabolism but they are toxic above their threshold levels. Ordinarily, they may enter the body in small amounts via respiration, ingestion, skin and drinking water. Some metals such as lead are not biologically significant in the body, and become toxic in the form of specific molecular complexes ( $\underline{9})$.

Television is primarily a mass medium for entertainment, education, news and advertising ( $\underline{10})$. People around the world are bombarded by advertising campaigns exhorting them to the latest, most fashionable models. As a result, television has become outdated and new models are introduced at a fast pace (11). The plastic in the television housing represents about $23 \%$ of the total weight (12). Televisions contain a large number of heavy metals, which can pollute the air when burned or leached into the soil and drinking water, especially if buried in landfills.

The aim of this study was to determine the heavy metal levels in the plastic housing of select television models and find out if any changes in the levels have occurred over the three decades (1998-2000). Such an investigation is of significance, considering the large quantities of plastics being generated and the current concerns about the waste management practices.

\section{MATERIALS AND METHOD}

Sample Collection: Fifteen television sets manufactured between 1980 and 2000 were collected based on their availability. Five TVs from each of the 1980's, 1990's and 2000's were used in this study. These obsolete TV's of different brands were collected mainly from TV repair shops in Ogbete main market in Enugu and the computer village in Lagos, Nigeria. The TVs were complete but faulty and were kept in storage for possible recycling of the parts other than the plastic housing. The information on these TVs, such as brand and year of manufacture were obtained from the labels or from the retailers or repair shops. The TV brands used in this study were: President, Sharp, Grundig, Toshiba, Olevia, Goodness, Bush, Panasonic, Pacific, Tatung, Saisho, Philips, LG and Sharp.

Sample Preparation and Digestion: The plastic housings of the TVs were separated and crushed to pieces. The plastic samples were digested at $120^{\circ} \mathrm{C}$ in a $1: 1$ ration mixture of $\mathrm{H}_{2} \mathrm{SO}_{4}(98 \%): \mathrm{HNO}_{3}(70 \% ; 10 \mathrm{~mL}$ per $1 \mathrm{~g}$ sample) and heated to near dryness. The digest was solubilized with $10 \mathrm{~mL}$ deionized water, filtered and suspended in $100 \mathrm{~mL}$ deionized water. Standard solutions of the suspended metals were prepared at two, four and six part per million (ppm) concentrations, and were aspirated into the burner to calibrate the atomic absorption spectrophotometer (AAS). The samples were analyzed for $\mathrm{Pb}, \mathrm{Ni}, \mathrm{Ag}, \mathrm{Zn}$, $\mathrm{Cr}, \mathrm{Cu}, \mathrm{V}, \mathrm{Co}$ and $\mathrm{Cd}$ by the AAS equipped with an air/acetylene flame.

Validation Method: Glassware was properly washed and the reagents were of analytical grades (Riedel-de Haen, Germany). The accuracy of instrumental methods and analytical procedures were validated, using standard addition method. This was done by determining the metal concentrations in triplicate samples of un-spiked and spiked plastic housing samples. Spiking was performed by adding 1-3 mL of the metal standard solution (Table 1) to $1 \mathrm{~g}$ of the sample, which was later subjected to the digestion procedure. The formula for calculating the percent recoveries was: $\%$ Recovery $=\frac{x-y}{z} \times 100$, where $\mathrm{x}$ was the concentration of spiked sample, $y$ was the concentration of un-spiked sample; and $\mathrm{z}$ was the spiking concentration (mg/L). Sample blanks, prepared by taking $10 \mathrm{~mL}$ of the mixture through the digestion procedure as the samples were analyzed for the metals. Table 1 shows the recoveries obtained via spiking of the samples with varying metal concentrations. Recoveries ranging from 92-96\% were obtained. This validates the analytical procedure used.

Statistical Analysis: Spearman's coefficient correlation analysis was carried out to establish the presence of the heavy metals versus the plastic samples for the three decades. Analysis of variance was also performed with SPSS version 16 to determine and compare the significant difference $(\mathrm{p}<0.05)$ in the metals detected for each decade.

\section{RESULTS}

The mean concentrations of heavy metals in the plastic housing of TVs manufactured in the 1980's, 1990's and 2000's are shown in Tables 2, 3 and 4, respectively. Lead was detected in only three samples manufactured in 1980; however, it was not detected in any of the 1990 's samples. Also, lead was detected in four out of the five samples manufactured in the 2000's. The mean concentrations of lead in the 1980's samples were much higher than the values obtained for 2000 samples. Silver was detected in only two 1980 samples while it was detected in all samples manufactured in the 1990's and 2000's. Much higher silver concentrations were detected in the 2000's samples compared to the other decades. Vanadium was detected in only one sample from the 1980's while it was detected in all samples for the 1990's and 2000's. Most of the other metals were detected in all of the samples across the three decades.

Table 5 represents the total mean concentrations of the heavy metals studied in the TV plastic housings for 1980's, 1990's and 2000's, and the TTLC values for the metals. The results were compared with the concentrations of heavy metals in electrical and electronic plastic material reported elsewhere and is presented in Table 6. Higher total mean concentrations of $\mathrm{Ni}, \mathrm{Ag}, \mathrm{V}, \mathrm{Co}$ and $\mathrm{Cd}$ were detected in the samples 
manufactured in 2000's while higher concentration of $\mathrm{Pb}$ and $\mathrm{Cu}$ were detected in the 1980's samples. The highest total mean concentration of $\mathrm{Zn}$ was documented for the 1990's samples. Table 7 presents the correlation analysis of the data. The analyzed data indicated that the concentration of heavy metals decreased as we progressed from 1980's to 2000's decades.
The analysis of variance (ANOVA) showed a significant difference $(p<0.05)$ between each element in the sample manufactured within the same decade which was expected due to the limitation of not finding same product in the three decades. However, the Toshiba TV housing for the 1980's and 2000's showed an increase in the concentration of heavy metals.

Table 1. Percentage Recovery of heavy metals in the Television Plastic Housing.

\begin{tabular}{|c|c|c|c|c|c|}
\hline Element & $\begin{array}{l}\text { Spiking (added) } \\
\text { conc.(mg/L) }\end{array}$ & $\begin{array}{l}\text { Conc. of spiked } \\
\text { sample (mg/L) }\end{array}$ & $\begin{array}{l}\text { Conc. of unspiked } \\
\text { sample (mg/L) }\end{array}$ & Recovered conc. & \% Recovery \\
\hline Mean \pm S.D & & & & & $95 \% \pm 0.01$ \\
\hline \multirow[t]{3}{*}{$\mathbf{P b}$} & 1.0000 & 0.9769 & 0.0769 & 0.9000 & 90 \\
\hline & 2.0000 & 1.9587 & 0.0069 & 0.9759 & 98 \\
\hline & 3.0000 & 2.9885 & 0.1111 & 0.9591 & 96 \\
\hline Mean \pm S.D & & & & & $95 \% \pm 0.04$ \\
\hline \multirow[t]{3}{*}{$\mathrm{Ni}$} & 1.0000 & 0.9989 & 0.0080 & 0.9909 & 99 \\
\hline & 2.0000 & 1.8670 & 0.0155 & 0.9258 & 93 \\
\hline & 3.0000 & 2.8538 & 0.0425 & 0.9371 & 94 \\
\hline Mean $\pm S . D$ & & & & & $95 \% \pm 0.03$ \\
\hline \multirow[t]{3}{*}{ Ag } & 1.0000 & 1.0002 & 0.0800 & 0.9202 & 92 \\
\hline & 2.0000 & 1.9856 & 0.0662 & 0.9194 & 92 \\
\hline & 3.0000 & 3.3002 & 0.5842 & 0.9053 & 91 \\
\hline Mean \pm S.D & & & & & $92 \% \pm 0.58$ \\
\hline \multirow[t]{3}{*}{ Zn } & 1.0000 & 1.5011 & 0.5116 & 0.9895 & 99 \\
\hline & 2.0000 & 3.7758 & 1.8189 & 0.9785 & 98 \\
\hline & 3.0000 & 3.9865 & 1.3244 & 0.8874 & 89 \\
\hline Mean $\pm S . D$ & & & & & $95 \% \pm 0.06$ \\
\hline \multirow[t]{3}{*}{$\mathrm{Cr}$} & 1.0000 & 0.9924 & 0.1402 & 0.8522 & 85 \\
\hline & 2.0000 & 2.0013 & 0.0410 & 0.9802 & 98 \\
\hline & 3.0000 & 2.9937 & 0.1235 & 0.9567 & 96 \\
\hline Mean $\pm S . D$ & & & & & $93 \% \pm 0.07$ \\
\hline \multirow[t]{3}{*}{$\mathrm{Cu}$} & 1.0000 & 1.0138 & 0.0202 & 0.9936 & 99 \\
\hline & 2.0000 & 1.8341 & 0.0404 & 0.8969 & 90 \\
\hline & 3.0000 & 2.9401 & 0.0580 & 0.9607 & 96 \\
\hline Mean \pm S.D & & & & & $95 \% \pm 0.05$ \\
\hline \multirow[t]{3}{*}{ V } & 1.0000 & 1.1263 & 0.1582 & 0.9621 & 96 \\
\hline & 2.0000 & 2.1753 & 0.3733 & 0.9010 & 90 \\
\hline & 3.0000 & 3.0183 & 0.1582 & 0.9534 & 95 \\
\hline Mean \pm S.D & & & & & $94 \% \pm 0.03$ \\
\hline \multirow[t]{3}{*}{ Co } & 1.0000 & 0.9871 & 0.0666 & 0.9205 & 92 \\
\hline & 2.0000 & 2.1931 & 0.1982 & 0.9975 & 100 \\
\hline & 3.0000 & 2.8813 & 0.0000 & 0.9604 & 96 \\
\hline Mean \pm S.D & & & & & $96 \% \pm 0.04$ \\
\hline \multirow[t]{3}{*}{ Cd } & 1.0000 & 1.0095 & 0.0703 & 0.9392 & 94 \\
\hline & 2.0000 & 1.9672 & 0.0523 & 0.9575 & 96 \\
\hline & 3.0000 & 2.8985 & 0.0111 & 0.9625 & 96 \\
\hline
\end{tabular}

Table 2. Mean concentration \pm standard deviation (mg / $\mathrm{kg}$ ) of heavy metal in plastic housing of Television produced in the 1980's.

\begin{tabular}{clllll}
\hline Heavy & \multicolumn{5}{c}{ Television Brand } \\
\cline { 2 - 6 } Metal & \multicolumn{1}{c}{ President } & \multicolumn{1}{c}{ Bush } & \multicolumn{1}{c}{ Grundig } & \multicolumn{1}{c}{ Toshiba } & \multicolumn{1}{c}{ Panasonic } \\
\hline $\mathbf{P b}$ & $9.44 \pm 1.87$ & $42.80 \pm 10.02$ & $11.53 \pm 2.27$ & $\mathrm{Nd}$ & $\mathrm{Nd}$ \\
$\mathbf{N i}$ & $\mathrm{Nd}$ & $1.76 \pm 0.32$ & $2.09 \pm 0.71$ & $3.72 \pm 2.54$ & $1.63 \pm 1.48$ \\
$\mathbf{A g}$ & $2.32 \pm 4.02$ & $\mathrm{Nd}$ & $\mathrm{Nd}$ & $5.33 \pm 4.62$ & $\mathrm{Nd}$ \\
$\mathbf{Z n}$ & $50.56 \pm 4.02$ & $37.99 \pm 2.99$ & $84.85 \pm 12.27$ & $166.77 \pm 37.04$ & $71.04 \pm 7.46$ \\
$\mathbf{C r}$ & $3.36 \pm 3.04$ & $25.67 \pm 6.67$ & $\mathrm{Nd}$ & $2.73 \pm 2.37$ & $3.81 \pm 3.81$ \\
$\mathbf{C u}$ & $4.70 \pm 0.84$ & $3.92 \pm 0.95$ & $2.93 \pm 0.72$ & $1.84 \pm 0.76$ & $2.91 \pm 0.16$ \\
$\mathbf{V}$ & $24.20 \pm 10.32$ & $\mathrm{Nd}$ & $\mathrm{Nd}$ & $\mathrm{Nd}$ & $\mathrm{Nd}$ \\
$\mathbf{C o}$ & $5.99 \pm 0.39$ & $3.46 \pm 0.28$ & $17.01 \pm 1.29$ & $11.67 \pm 0.62$ & $8.38 \pm 0.39$ \\
$\mathbf{C d}$ & $1.08 \pm 0.16$ & $3.51 \pm 0.36$ & $1.92 \pm 0.11$ & $2.26 \pm 0.21$ & $4.21 \pm 0.26$ \\
\hline $\mathrm{Nd}=$ not detected & & & &
\end{tabular}

Table 3. Mean concentration \pm standard deviation (mg / $\mathrm{kg}$ ) of heavy metal in plastic housing of Television produced in the 1990's.

\begin{tabular}{clllll}
\hline $\begin{array}{c}\text { Heavy } \\
\text { Metal }\end{array}$ & \multicolumn{1}{c}{ Philips } & \multicolumn{1}{c}{ Goodness } & \multicolumn{1}{c}{ Sharp } & \multicolumn{1}{c}{ Saisho } & \multicolumn{1}{c}{ Tatung } \\
\hline $\mathbf{P b}$ & $\mathrm{Nd}$ & $\mathrm{Nd}$ & $\mathrm{Nd}$ & $\mathrm{Nd}$ & $\mathrm{Nd}$ \\
$\mathbf{N i}$ & $1.49 \pm 1.49$ & $\mathrm{Nd}$ & $1.06 \pm 0.38$ & $3.47 \pm 3.13$ & $1.34 \pm 1.05$ \\
$\mathbf{A g}$ & $69.16 \pm 32.91$ & $2.62 \pm 4.54$ & $4.16 \pm 3.88$ & $4.98 \pm 4.31$ & $0.09 \pm 0.04$ \\
$\mathbf{Z n}$ & $205.09 \pm 9.01$ & $213.25 \pm 30.48$ & $134.59 \pm 7.84$ & $168.55 \pm 19.99$ & $76.96 \pm 6.93$ \\
$\mathbf{C r}$ & $3.34 \pm 3.08$ & $3.39 \pm 3.12$ & $5.94 \pm 5.90$ & $4.49 \pm 3.99$ & $3.98 \pm 3.98$ \\
$\mathbf{C u}$ & $2.37 \pm 0.73$ & $3.67 \pm 0.60$ & $4.18 \pm 0.52$ & $2.28 \pm 0.70$ & $1.31 \pm 1.13$ \\
$\mathbf{V}$ & $12.03 \pm 20.84$ & $28.61 \pm 11.42$ & $23.88 \pm 20.68$ & $23.72 \pm 10.20$ & $31.99 \pm 5.10$ \\
$\mathbf{C o}$ & $5.74 \pm 0.10$ & $5.85 \pm 0.35$ & $7.64 \pm 0.07$ & $9.94 \pm 2.24$ & $12.82 \pm 1.91$ \\
$\mathbf{C d}$ & $5.64 \pm 0.33$ & $1.16 \pm 0.18$ & $4.54 \pm 0.42$ & $5.37 \pm 0.26$ & $3.55 \pm 0.29$ \\
\hline
\end{tabular}


Table 4. Mean concentration \pm standard deviation $(\mathrm{mg} / \mathrm{kg}$ ) of heavy metal in plastic housing of Television produced in the 2000's.

\begin{tabular}{clllll}
\hline \multirow{2}{*}{$\begin{array}{c}\text { Heavy } \\
\text { Metal }\end{array}$} & \multicolumn{1}{c}{ Pacific } & \multicolumn{1}{c}{ LG } & \multicolumn{1}{c}{ Sharp base } & \multicolumn{1}{c}{ Olevia } & \multicolumn{1}{c}{ Toshiba } \\
\cline { 2 - 6 } $\mathbf{P b}$ & $5.41 \pm 1.11$ & $0.38 \pm 0.33$ & $0.43 \pm 0.19$ & $\mathrm{Nd}$ & $0.39 \pm 0.16$ \\
$\mathbf{N i}$ & $1.62 \pm 0.33$ & $1.70 \pm 1.54$ & $2.29 \pm 2.07$ & $1.19 \pm 0.39$ & $7.15 \pm 7.53$ \\
$\mathbf{A g}$ & $46.59 \pm 25.12$ & $57.69 \pm 34.48$ & $4.93 \pm 4.27$ & $48.75 \pm 42.22$ & $44.14 \pm 47.78$ \\
$\mathbf{Z n}$ & $138.89 \pm 31.94$ & $50.17 \pm 1.46$ & $102.51 \pm 12.79$ & $56.13 \pm 6.45$ & $218.73 \pm 37.83$ \\
$\mathbf{C r}$ & $5.52 \pm 1.8$ & $12.81 \pm 0.81$ & $\mathrm{Nd}$ & $3.16 \pm 2.91$ & $4.81 \pm 1.24$ \\
$\mathbf{C u}$ & $1.44 \pm 0.47$ & $3.83 \pm 3.25$ & $3.14 \pm 0.59$ & $1.68 \pm 0.69$ & $1.83 \pm 0.75$ \\
$\mathbf{V}$ & $22.92 \pm 19.85$ & $24.14 \pm 20.90$ & $39.41 \pm 27.54$ & $11.37 \pm 19.70$ & $35.50 \pm 5.62$ \\
$\mathbf{C o}$ & $16.51 \pm 3.31$ & $\mathrm{Nd}$ & $6.44 \pm 0.05$ & $6.86 \pm 0.42$ & $33.36 \pm 9.09$ \\
$\mathbf{C d}$ & $2.37 \pm 0.38$ & $4.76 \pm 3.56$ & $4.28 \pm 0.33$ & $4.99 \pm 0.41$ & $5.02 \pm 0.55$ \\
\hline
\end{tabular}

Table 5. Total mean concentration of heavy metals (mg/kg) in the television plastic housing in the 1980's, 1990's and 2000's and the TTLC of the

\begin{tabular}{|c|c|c|c|c|c|}
\hline \multirow{2}{*}{$\begin{array}{l}\text { Heavy } \\
\text { Metal }\end{array}$} & \multicolumn{3}{|c|}{ Mean \pm S.D (Range), $n=5$} & \multirow{2}{*}{ TTLC (mg/kg) } & \multirow{2}{*}{ N > TTLC } \\
\hline & 1980 & 1990 & 2000 & & \\
\hline $\mathbf{P b}$ & $\begin{array}{l}12.75 \pm 17.61 \\
(\mathrm{Nd}-42.80)\end{array}$ & $\begin{array}{l}0.00 \pm 0.00 \\
(\mathrm{Nd})\end{array}$ & $\begin{array}{l}1.32 \pm 2.29 \\
(\mathrm{Nd}-5.41)\end{array}$ & 1000 & Nil \\
\hline $\mathbf{N i}$ & $\begin{array}{l}1.84 \pm 1.32 \\
\text { (Nd-3.72) }\end{array}$ & $\begin{array}{l}1.47 \pm 1.26 \\
\text { (Nd-3.47) }\end{array}$ & $\begin{array}{l}2.79 \pm 2.47 \\
(1.62-7.15)\end{array}$ & 2000 & Nil \\
\hline Ag & $\begin{array}{l}1.53 \pm 2.35 \\
(\mathrm{Nd}-5.33)\end{array}$ & $\begin{array}{l}16.19 \pm 29.66 \\
(0.09-69.16)\end{array}$ & $\begin{array}{l}40.42 \pm 20.49 \\
(4.93-57.69)\end{array}$ & 500 & Nil \\
\hline Zn & $\begin{array}{l}82.24 \pm 50.59 \\
(37.99-166.77)\end{array}$ & $\begin{array}{l}159.69 \pm 55.86 \\
(76.96-213.25)\end{array}$ & $\begin{array}{l}113.29 \pm 69.18 \\
(50.17-218.73)\end{array}$ & 5000 & Nil \\
\hline $\mathrm{Cr}$ & $\begin{array}{l}7.12 \pm 10.48 \\
(\mathrm{Nd}-25.67)\end{array}$ & $\begin{array}{l}4.23 \pm 1.07 \\
(3.34-5.94)\end{array}$ & $\begin{array}{l}5.26 \pm 4.73 \\
(\mathrm{Nd}-12.81)\end{array}$ & 2500 & Nil \\
\hline $\mathbf{C u}$ & $\begin{array}{l}3.26 \pm 1.09 \\
(1.84-4.70)\end{array}$ & $\begin{array}{l}2.76 \pm 1.15 \\
(1.31-4.17)\end{array}$ & $\begin{array}{l}2.39 \pm 1.05 \\
(1.44-3.83)\end{array}$ & 2500 & Nil \\
\hline $\mathbf{V}$ & $\begin{array}{l}4.84 \pm 10.82 \\
(\mathrm{Nd}-24.20)\end{array}$ & $\begin{array}{l}24.05 \pm 7.55 \\
(12.03-31.99)\end{array}$ & $\begin{array}{l}26.67 \pm 11.12 \\
(11.37-39.41)\end{array}$ & 2400 & Nil \\
\hline Co & $\begin{array}{l}9.30 \pm 5.27 \\
(3.46-17.01)\end{array}$ & $\begin{array}{l}8.40 \pm 3.00 \\
(5.85-12.8)\end{array}$ & $\begin{array}{l}12.63 \pm 12.99 \\
(\mathrm{Nd}-33.36)\end{array}$ & 8000 & Nil \\
\hline Cd & $\begin{array}{l}2.59 \pm 1.25 \\
(1.08-4.21)\end{array}$ & $\begin{array}{l}4.05 \pm 1.81 \\
(1.16-5.64)\end{array}$ & $\begin{array}{l}4.28 \pm 1.11 \\
(2.37-5.03)\end{array}$ & 100 & Nil \\
\hline
\end{tabular}

$\mathrm{n}=$ number of samples, $\mathrm{N}=$ number of samples above TTLC

Table 6. Heavy metal levels $(\mathrm{mg} / \mathrm{kg}$ ) reported in electrical and electronic plastic materials

\begin{tabular}{|c|c|c|c|c|c|c|c|c|c|c|}
\hline \multirow{2}{*}{$\begin{array}{l}\text { Electrical \& electronics } \\
\text { device }\end{array}$} & \multicolumn{9}{|c|}{ Heavy Metals } & \multirow[t]{2}{*}{ References } \\
\hline & $\mathbf{P b}$ & Cd & $\mathbf{N i}$ & Zn & $\mathrm{Cu}$ & $\mathrm{Cr}$ & $\mathbf{A g}$ & Co & $\mathbf{V}$ & \\
\hline Plastic from electronic waste & 17.41 & 5.71 & - & 360 & 570 & 8.38 & - & - & - & $(21)$ \\
\hline Mobile phone & 10140 & 2.93 & 9247 & 11007 & 203000 & 958 & 65.9 & 241.3 & $\mathrm{Nd}$ & $(22)$ \\
\hline Cell phone & 4667 & $\mathrm{Nd}$ & 1946 & $\mathrm{Nd}$ & $\mathrm{Nd}$ & 1470 & 235 & 145 & $\mathrm{Nd}$ & (18) \\
\hline TV plastic cabinet & 295 & 6.7 & - & 75 & 392 & - & - & - & - & (23) \\
\hline Waste mobile phone plastic & 58.3 & 69.9 & 432 & - & - & - & 403 & - & - & (20) \\
\hline
\end{tabular}

Table 7. Correlation across the three decades.

\begin{tabular}{|c|c|c|c|c|}
\hline Metal & Decade & 1980s & 1990s & $2000 s$ \\
\hline & 1980s & 1.00 & & \\
\hline \multirow[t]{3}{*}{$\mathbf{P b}$} & 1990s & $\mathrm{a}$ & 1.00 & \\
\hline & $2000 \mathrm{~s}$ & $-0.672 *$ & $\mathrm{a}$ & 1.00 \\
\hline & $1980 \mathrm{~s}$ & 1.00 & & \\
\hline \multirow[t]{2}{*}{$\mathrm{Ni}$} & $1990 \mathrm{~s}$ & 0.468 & 1.00 & \\
\hline & $2000 \mathrm{~s}$ & -0.159 & -0.309 & 1.00 \\
\hline \multirow[t]{3}{*}{ Ag } & $1980 \mathrm{~s}$ & 1.00 & & \\
\hline & $1990 \mathrm{~s}$ & 0.325 & 1.00 & \\
\hline & $2000 \mathrm{~s}$ & 0.226 & -0.022 & 1.00 \\
\hline \multirow[t]{3}{*}{ Zn } & $1980 \mathrm{~s}$ & 1.00 & & \\
\hline & $1990 \mathrm{~s}$ & $-0.536^{*}$ & 1.00 & \\
\hline & $2000 \mathrm{~s}$ & -0.104 & $-0.571^{*}$ & 1.00 \\
\hline \multirow[t]{3}{*}{$\mathrm{Cr}$} & $1980 \mathrm{~s}$ & 1.00 & & \\
\hline & $1990 \mathrm{~s}$ & $-0.685^{* *}$ & 1.00 & \\
\hline & $2000 \mathrm{~s}$ & $0.872^{* *}$ & $-0.712^{* *}$ & 1.00 \\
\hline \multirow[t]{3}{*}{$\mathrm{Cu}$} & $1980 \mathrm{~s}$ & 1.00 & & \\
\hline & $1990 \mathrm{~s}$ & 0.262 & 1.00 & \\
\hline & $2000 \mathrm{~s}$ & -0.317 & 0.050 & 1.00 \\
\hline \multirow[t]{3}{*}{ V } & $1980 \mathrm{~s}$ & 1.00 & & \\
\hline & $1990 \mathrm{~s}$ & $-0.684^{* *}$ & 1.00 & \\
\hline & $2000 \mathrm{~s}$ & -0.346 & -0.066 & 1.00 \\
\hline \multirow[t]{3}{*}{ Co } & $1980 \mathrm{~s}$ & 1.00 & & \\
\hline & $1990 \mathrm{~s}$ & 0.500 & 1.00 & \\
\hline & $2000 \mathrm{~s}$ & 0.092 & 0.496 & 1.00 \\
\hline \multirow[t]{3}{*}{ Cd } & $1980 \mathrm{~s}$ & 1.00 & & \\
\hline & $1990 \mathrm{~s}$ & $-0.682^{* *}$ & 1.00 & \\
\hline & $2000 \mathrm{~s}$ & $0.514^{*}$ & 0.054 & 1.00 \\
\hline
\end{tabular}

* Correlation was significant at the 0.05 level (2-tailed).

** Correlation was significant at the 0.01 level (2-tailed).

a Could not be computed because at least one of the variables is constant. 


\section{DISCUSSION}

Based on the results, there is no particular trend in the concentrations of heavy metals in the plastic samples across the three decades. This might be in part due to differences in the manufacturing of the TV housings. Overall, we observed that the concentration of cadmium, silver and vanadium increased steadily across the three decades. While cadmium could have been incorporated as stabilizer and colorant in plastics, silver might have resulted from contamination with soldering materials in the TV housings. Specifically, replacing lead in soldering materials with bismuth, silver and copper may explain the presence of silver (13). Vanadium might also have originated from contamination during the manufacturing processes.

In general, the TV housings studied contained less than $50 \mathrm{mg} / \mathrm{kg} \mathrm{Pb}, \mathrm{Ni}, \mathrm{Cr}, \mathrm{Cu}, \mathrm{V}$, Co, and Cd. However, 98\% and $7 \%$ of the samples contained more than $50 \mathrm{mg} / \mathrm{kg}$ $\mathrm{Zn}$ and $\mathrm{Ag}$, respectively. Also, the concentration of zinc was high across the studied decades, which was expected because zinc is used as a stabilizer, filler and colorant in plastics. Cobalt and chromium could have also been used as pigments, copper as biocides, lead and nickel as stabilizer or from the soldering materials in the TV industry. The solder compositions include $\mathrm{Sn} / \mathrm{Ag} / \mathrm{Cu}, \mathrm{Sn} / \mathrm{Ag}$, and $\mathrm{Sn} / \mathrm{Bi} / \mathrm{Ag}$ alternatives. However, the $\mathrm{Sn} / \mathrm{Ag} / \mathrm{Cu}$ solders represent the preferred alternatives (14). Although these metals are useful, their negative effect on the environment and human health cannot be ignored, hence the need for monitoring their presence. These metals are potential environmental contaminants and can find their way into the foods, causing human health concerns. They are given special attention throughout the world due to their ubiquitous nature and toxic effects even at very low concentrations ( $\underline{15})$. Essentially, heavy metals have become a focus of public concern since analytical techniques have made it possible to detect them even at trace levels.

There have been governmental attempts to regulate these metal levels in plastics. The first attempt was introduced in mid 1990s by the European Community. The European Community "Packaging Directive" (EC Directive 94/62/EEC) has set the total amount of metals such as $\mathrm{Cd}, \mathrm{Cr}, \mathrm{Hg}$, and $\mathrm{Pb}$ in plastic materials to be less than $100 \mathrm{mg} / \mathrm{kg}(\underline{16,17})$. Another European Union (EU) Directive (91/338/EC) sets the maximum allowable concentration of cadmium in plastics for consumer goods at $100 \mathrm{mg} / \mathrm{kg}(\underline{18,19})$. Similarly, the EU Directive on the Restriction of Hazardous Substances, RoHS (Directive 2002/95/EC), which became effective in July 2006, calls on manufacturers to be environmentally responsible and not use any homogenous material, parts or subassemblies that contains a maximum value of $0.1 \%$ by weight for $\mathrm{Pb}$, $\mathrm{Hg}, \mathrm{Cr}^{6+}$, polybrominated biphenyls (PBB), polybrominated diphenyl ethers (PBDE), and $0.01 \%$ by weight in homogenous materials for $\mathrm{Cd}$. The Total test is a chemical digestion procedure developed by the Department of Toxic Substances Control (20) to determine the total amount of a specific constituent in a sample material. This requires the chemical digestion of the sample to obtain the soluble and insoluble fractions. This analysis determines the total concentration of each target analyte in a sample. When any target analyte exceeds the toxicity threshold limit concentration (TTLC), the waste is classified as hazardous and the code is determined by the compounds that failed TTLC $(\underline{16,18})$.

As presented in Table 5, the lead results were less than $1000 \mathrm{mg} / \mathrm{kg}$; and cadmium and chromium concentrations were generally less than $100 \mathrm{mg} / \mathrm{kg}$. These levels are the maximum allowable concentrations in homogenous components of electronic products by the Restriction of Hazardous Substances (RoHS) Directive. Although $\mathrm{Zn}, \mathrm{Cu}$ and $\mathrm{Ag}$ were relatively high, all of them were below the TTLC. Hence, the plastic housing of the examined TVs do not constitute significant hazards; however, there is a need for their appropriate management and disposal. As seen in Table 6, the concentrations of heavy metals in the TV plastic housings were lower than those reported in previous studies $(\underline{14,20-23})$.

\section{CONCLUSION}

The results of this study showed that plastic housings of TVs manufactured between 1980 and 2000 contained varying amounts of heavy metals (lead, nickel, silver, zinc, chromium, copper, vanadium, cobalt and cadmium), which pollute the air when burned and leached into the soil and drinking water or if buried in landfills. Considering that the mean concentrations of the heavy metals were all below the levels set by the regulatory agencies, it can be deduced that the levels for TV plastic housings do not constitute a significant danger if managed appropriately. Therefore, policies guiding the disposal of electrical and electronic devices should be introduced to enhance their efficient and safe management.

\section{ACKNOWLEDGEMENTS}

The authors are grateful to their research assistant and laboratory attendants who wished to remain anonymous.

\section{CONFLICT OF INTEREST}

The authors declare no conflict of interest. This paper was extracted from a M.Sc. thesis project conducted by Chioma Okenwa-ani submitted to the Department of Pure and Industrial Chemistry, University of Nigeria at Nsukka, Nigeria.

\section{REFERENCES}

1. Sinha S. Downside of the Digital Revolution. Published in Toxics Link; 2007 [cited 2007 December 28]. Available from: http://www.toxicslink.org/art-view.php?id=124

2. Fisher MM, Mark FE, Kingsbury T, Vehlow J, Yamawaki T. Electrical and electronic products, In: Proceedings of the International Symposium on Electronics and the Environment, Energy recovery in the sustainable recycling of plastic from end-of-life. New Orleans, LA, USA; 2005. 
3. Balakrishnan RB, Anand KP, Chiya AB. Electrical and electronic waste: a global environmental problem. J Waste Manag Res. 2007;25:307-317.

4. Antrekowitsch H, Potesser M, Spruzina W, Prior F. Metallurgical recycling of electronic scrap, The Minerals, Metals and Materials Society (TMS), 2006.

5. Association of Plastics Manufacturers in Europe (APME). An analysis of plastics consumption and Recovery in Europe. APME, Brussels, Belgium. 2003. [Cited August 10, 2015]. Available from: www.plasticseurope.org.

6. Piorek S. Feasibility of analysis and screening of plastics for heavy metals with portable X-ray fluorescence analyzer with miniature X-ray tube, Paper Presented at the Global Plastics Environmental Conference, GPEC2004, Detroit, MI, USA; 2004.

7. Duruibe JO, Ogwuegbu MO, Egwurugwu JN. Heavy metal pollution and human biotoxic effects. Int J Phy Sci. 2001;2(5):112-118.

8. Sheftel VO. Indirect food additives and polymers. Migration and toxicology. Boca Ranton: Lewis Publishers, CRC Press LLL; 2000.

9. Lenntech BV. Heavy Metals. 2012 [Cited 2012, May 10]. Available from: www.lenntech.co./periodic.periodicchart,htm

10. Diggs-Brown B. Strategic Public Relations: Audience Focused Practice. $1^{\text {st }}$ edition Wadsworth Publishing; 2011.

11. Leena O. Case Study on the Environmental Impacts of a Mobile Phone, Electronics Goes Green 2000+, Berlin. 2000; [cited 2012 April 10]. Available from: www.informinc.org/wirelesswaste.php.

12. Robinson BH. E-waste: An assessment of global production and environmental impacts. Sci Tot Environ. 2009;408:183-191.

13. Hansen E, Nilsson NH, Lithner D, Lassen C. Hazardous Substances: In Plastic Materials. Prepared by COWI in cooperation with Danish Technological Institute, 2013. Available online at: http://www.miljodirektoratet.no/old/klif/publikasjoner /3017/ta3017.pdf

14. Nnorom IC, Osibanjo O. Toxicity Characterization of Waste Mobile Phone Plastics. J Haz Mat. 2009;161: 183188.
15. Duffus JH. Heavy metals - A meaningless term? Pure Appl Chem. 2002;74(5):793-807.

16. European Parliament and Council Directive 94/62/EC of 20 December 1994 on packaging and packaging waste. Official J. L. 1994;365:10-23.

17. European Commission. Chemicals/REACH: Six dangerous substances to be phased out by the EU. Press release; 17 February 2011 [Cited March 20, 2011). Available online at:

http://europa.eu/rapid/pressReleasesAction.do?referen ce $=$ IP $/ 11 / 196 \&$ format $=$ HTML\&aged $=0 \&$ language $=E N \& g$ uiLanguage $=$ en

18. Plastics Europe. Compelling facts about plastics. An analysis of European plastics production, demand and recovery for 2008. Brussels: Plastics Europe; 2009. Available online at: http://www.plasticseurope.org/Documents/Document/ 20100225141556

Brochure_UK_FactsFigures_2009_22sept_6_Final20090930-001-EN-v1.pdf

19. European Commission. Commission directive 2011/8/EU of 28 January 2011 amending Directive 2002/72/EC as regards the restriction of use of Bisphenol A in plastic infant feeding bottles. 2011 [Cited February 10, 2015]. Available online at: http://eurlex.europa.eu/LexUriServ.do?uri=0J:L:2011:0 26-:0011:0014:EN:PDF.

20. Department of Toxic Substances Control. Determination of regulated elements in seven types of discarded consumer electronic products. California: Hazardous Material Laboratory, 2004.

21. Dimitrakakis E, Bilitewski B, Gidarakos E. Determination of heavy metals \& Halogens in Plastics from Electronic Waste. Int J Environ Waste Managt. 2007;29:2700-2706.

22. Lincoln JD, Ogunseitan OA, Shapiro AA, Saphores J-DM. (2004). Leaching assessment of hazardous materials in cellular telephones. Environ. Sci. Technol. 2004;41:25722578.

23. Matsuto $\mathrm{T}$, Jung $\mathrm{CH}$, Tanaka N. Material and heavy metal balance in a recycling facility for home electrical appliances. Waste Managt. 2004;24:425-436. 